\title{
HVOR STORT ER DET POLITISKE SYSTEM?
}

I de to forste munre af Politica startede P. Nannestad olsen og $J$ an Henrik Nyheim en dabat om idehistorien. Nyheim dømte de nannestadske funderinger over 'hvorfor' vi beskæftiger os med disciplinen til at vare personlige problemer for forskeren og som sadanne hans forskning principielt uvedkommende (jeg er heri enig med Nyheim). Istedet skitserer Nyheim tanker angl̊ende idehistoriens 'hvordan', der med fast forankring $i$ empirien understreger den situation dansk politologi er $i$ endnu: tag til Norge, min faler! Eller som Oehlenschläger sagde det: 'stormenes Sluser/Bryde med Vælde./ Over Norges Fjelde/ Til Danmarks dale' - de forklarede gamle skulle sig kanske atter samle; til eftertanke.

Dog mener jeg ikke, Nyheims begrundelse for at afvise diskussionen om 'hvorfor' er tilstrækkelig. 'Al systematisk vitenskapelig arbeide er verdifullt, fordi det fører til ny kunnskap' mener Nyheim. Det er sikkert unfair at hvase hyperfaktualist efter Nyheim, men s\& langt $i$ retning af det empiridyrkende synes han dog at være, at han ikke overvejer det virkelige spørgsmål om 'hvorfor' vi beskæftiger os med idehistorie eller for den sags skyld anden videnskab. For at komme ind til dette spørgsmål, synes det vigtigt at sondre den af Nyheim så højt priste analyse af den politiske argumentation ud og istedet koncentrere sig om de mere sammenhængende idealdannelser omkring samfundsindretningen. Ikke fordi argumentationsanalysen er uvigtig, men fordi den uhjælpeligt forbliver en detailanalyse. I det følgende søger jeg at besvare problemet om 'hvorfor idehistorie'? ud fra det synspunkt, at den gængse arbitrære afgrænsning af det politiske system er uholdbar, og at idehistorien kan hjælpe os til at se dette.

Samfundet har flere undersystemer, et af dem er det politiske system. Systemet er summen af de handlinger, eller aspekter heraf, som er relevante ud fra vor definition af politik: "fordelingen af værdier med gyldighed for samfundet, dvs. at de pågældende er af den opfattelse at de bør eller ma tage den til følge". (E. Rasmussen, Komparativ Politik, s. 102). Der er altsa ikke tale om et system af organer, men af funktionelle handlinger.

Men hvor stort er da det politiske system? spørgșmallet besvares 
indirekte, når man indenfor idehistorien taler om fx. totalitær og partiel ideologi. Den totalitære ideologi (kommunisme, nazisme) politiserer samtlige livets omrader, ingen handling er fredet som horende til en privat sfære. Ikke kun adfæren, men ogsa tanken er det totalitære regime vedkommende, hvorved det skiller sig ud fra det mere banale diktatur. Den partielle ideologi vil omvendt påstå, at en del af menneskets adfærd og vel alle dets tanker er udenfor den sfære, der bør reguleres af politiske beslutninger; eksempel herpa er $i$ gængs opfattelse liberalismen.

Den for samfundet gyldige værdifordeling karakteriseres ved at være autoritativ, hvilket som nævnt betyder, "at de pagældende er af den opfattelse, at de bør eller ma tage den til følge". Pa dette easton-rasmussenske sprog foretages udsondringen af det politiske omrade $i$ totalitære respektive partielle ideologier saledes, at al den nævnte fordeling er autoritativ $i$ et samfund hyldende den første, men ikke $i$ et samfund hyldende den anden ideologi. Graden af totalitet angiver det autoritatives udstrækning, kunne man sige. Der er salledes bragt smuk overensstemmelse imellem det gængse idehistoriske og det moderne approach. Den følgende kritik er heller ikke rettet imod Erik Rasmussens begrebsapparat, allerede fordi han udtrykkeligt bemarker, at det mest er relevant overfor vestlige, modeme systemer. Kritikken prøver nærmere at trækkeandre approaches ind $i$ disse kussionen.

Hvis man ikke anlægger en systembetragtning $i$ første instans, men behandler ideologier på mere filosofisk manér, opstår akkurat problemet om det systematiske! Eftersom mange klassiske ideologier midlertid lader sig betagte som idesystemr ( de udvikles logisk tvingende fra valgte axiomer) og ikke kun som idekomplekser (uden. nodvendig indre sammenhæng), løses problemet dog af sig selv, fordi det politiske system, altsa indholdet af "autoritativ", kan deduceres af den systematiske ideologi (ex: Hobbes).

Hvad der her noget speget er kaldt "filosofisk manér" dækker over det monster, hvorefter det typiske idesystem er opbygget: en undersøgelse af mennesket konkluderende $i$ nogle rettigheder, behov, karakteregenskaber el. lign., hvorudfra ideologien deduceres(ex: igen Hobbes, den unge Marx, utilitaristerne etc.). Hvilkèt resultat man når til m.h.t. samfundets indretning afhænger af, hvad man har anset for at "definere" mennesket. I de ideologier, der overfor og andre steder kaldes totalitære, er der tale om en fornægtelse af 
individets autonimi; $i$ de partielle hævdes netop individets autonomi. Det kunne se ud som om denne forskel ikke lod sig reducere. Imidlertid vil jeg foresla en radikalisering af tanken derhen, at begge ideologier - her ikke anskuet som samfundssystemer, men "menneske-definitioner" - er lige totalitære $i$ betydningen altomfattende, og at enhver systematisk ideologi ma være totalitær $i$ denne forstand. Nar nemlig liberalisten i hovedsagen tillægger samfundslivet at dirrigeres af det private initiativ, har han lige fuldt taget stilling til, hvordan hele samfundet skal indrettes, som nazisten har, nar derne siger, at individet er intet, mens folket eller staten er alt. At vælge passiviteten er også at vælge. Oversat til Easton \& Rasmussen betyder denne radikalisering, at begrebet "autoritativ" mister sin sondrende evne - al fordeling er sådan set lige autoritativt bestemt af ideologien. Blot er altsa det autoritative flyttet fra at være en egenskab ved det politiske system til at vare en egenskab ved det idesystem, der ligger til grund herfor.

Foruden af et begrebs stringens afhænger dets nytte af " om det er frugtbart for forstielsen af de fænomener det skal belyse" (Erik Rasmussen, anf.værk, s.102). Dette må kræve en anticiperet opfattelse af begrebet politik eller af autoritativ fordeling eller lignende. Selvfølgelig ma man have en sadan opfattelse inden man begynder overhovedet at beskæftige sig begrebsmæssigt med et emne, men burde man sa ikke foretage en kontra-prøve af sit begrebs nytte, når først det er konstrueret? Altsa: dækker difinitionen af autoritativ ("at de pagældende er af den opfattelse at de bør eller ma tage den (fordelinger) til følge") over andre fænomener end politisk autotitet? Jeg mener ja, og det grunder jeg $p \&$ velnok en knap sa introspektiv opfattelse. Det er ikke afgørende for et menneske, om fordelingen fastsættes af politiske myndigheder eller private, fx. økonomiske strukturer. Han "ma tage den til følge" alligevel. Om hans opfattelse heraf er positiv eller negativ, kan vi ikke vide. Bag denne indvending lurer velnok opfattelsen af, at politik i sidste instans handler om magten - og at al magtudøvelsen er politisk relevant.

III

Efter at idehistorien nu har kritiseret det politiske systems arbitrære afgrænsning, kan kritikken passende sendes tilbage med spørgsmallet om idehistcriens afgrænsning. Det er altsa problemet om implicite relevanskriterier, der skal rodes $i$.

Vi kan ikke forbruge alt menneskeligt "huskestof", men ma udvæl- 
ge det væsentlige; hvad er det? Det står vi ikke helt frit i valget af! Fordi historiens politiske ideer indgår som motivation for vort eget adfærdsvalg, ma ideerne konfronteres med det begreb vi nu gør os om vort pclitiske system og dets størrelse. Hvis vi idag definerer det politiske system langt videre (dvs: udvider hvad vi kalder autoritativt) end $\mathrm{fx}$. den tidlige liberalist gjorde det, s̊ ma vi se bort fra det konkrete deduktionsarbejde, liberalisten foretog for 150 år siden til sit snævrere politiske system, sł sandt som idehistorie ikke børe være ren skolastik, men frugtbar for forstalelsen af relevante fænomener. (I denne forbindelse diskuteres ikke, om der er mulighed for at opstille komparative funktionelle beskrivelser af sa forskellige systemer henover de store strukturelle forskelle, men det er selvsagt spændende). Nar fx. liberalistens axiom(er) er fundet frem, ex det så, at det er vigtigt at forsta det $i$ den radikale forstand totalitære ogs\& $i$ de sakaldt partielle ideologier. Hvis nemlig vi binder os til, at liberalismen var partiel, er den død i praksis og teori med det politiske system, der angav dens partielle karakter. Enhver systematisk ideologi, dvs. enhver sådan med axiomer grundet pa, hvad jeg klodset har kaldt en"menneske-definition", er en stillingtagen til ethvert spørgsmål indenfor det brede univers, der funktionelt kan difineres som "fordeling af verdier med gyldighed for samfundet". Det relative, der gør ideologien partiel, er alene hvad man lægger $i$ "gyldighed" ellex autcritativ.

Hvis denne re-deduktion fra gamle axiomer er mulig, skulle denne opfattelse kunne danne basis for det relevanskriterium, vi ma anvende overfor idehistoriens umadelige stof. Den værdipræmis må også med, at jeg anser idehistorien som en integreret del af vort politiske liv idag. Den komparative funktionsanelyse vil måske ikke strække til over så store forskelle, men et eksempel har vi da i middelalderens kunstige fastholdelse af Aristcteles' m.fl.s. blandede styreform ganske p\& tværs af de herskende strukturer. Pa mindre, "egentligt" partielle, områder kunne lignende analyser måske nemmere foretages.

Til slut vil jeg ogs̊ vedstå den svaghed, der ligger $i$ den analytisk meget skarpe adskillelse, der her er sket af idesystem (eller rettere ideaxiom) og politisk system. Men den "eviggyldighed", der herved tillægges visse politiske ideer, er vel i sidste ende netop begrundelse for overhovedet at beskæftige sig med idehistorien. 